\title{
Exacerbations in cystic fibrosis: 4 - Non-cystic fibrosis bronchiectasis
}

${ }^{1}$ Department of Respiratory Medicine, Royal Children's Hospital and Child Health Division, Menzies School of Health Research, Charles Darwin University, Brisbane, Australia;

${ }^{2}$ Lung Defence Unit, Papworth Hospital NHS Trust, Cambridge, UK

Correspondence to: Dr A B Chang, Department of Respiratory Medicine, Royal Children's Hospital, Herston Road, Brisbane, Queensland 4029, Australia; annechang@ ausdoctors.net

Received 4 May 2006 Accepted 27 November 2006

\author{
A B Chang, ${ }^{1}$ D Bilton ${ }^{2}$
}

\begin{abstract}
Bronchiectasis unrelated to cystic fibrosis (CF) is increasingly recognised as an important and major primary respiratory disease in developing countries. In affluent countries, bronchiectasis is also increasingly recognised in subsections of communities (such as indigenous peoples) as well as a co-existent disease/co-morbidity and disease modifier in respiratory diseases such as chronic obstructive pulmonary disease. The epidemiology, pathogenesis, prevention and management of exacerbations of non-CF bronchiectasis are reviewed. There are few data on all aspects of exacerbations in bronchiectasis. Some of the management issues are common to non-CF and CF bronchiectasis, but it would be unwise to extrapolate from CF studies to non-CF bronchiectasis. In some situations this may be harmful.
\end{abstract}

Bronchiectasis, previously termed an "orphan disease", is increasingly recognised as a major cause of respiratory morbidity, not only in developing countries ${ }^{12}$ but also in children and adults in affluent countries. ${ }^{3-7}$ Bronchiectasis unrelated to cystic fibrosis (CF) is caused by-or associated with-many aetiologies ranging from congenital/ genetic illness (primary immunodeficiency, primary ciliary dyskinesia, Mounier-Kuhn syndrome) to retained airway foreign body. Also, the presence of bronchiectasis in common respiratory diseases such as chronic obstructive pulmonary disease $(\mathrm{COPD})^{8}$ and uncommon respiratory diseases such as bronchiolitis obliterans ${ }^{9}$ or sarcoidosis ${ }^{10}$ as well as systemic disease (eg, autoimmune diseases such as rheumatoid arthritis ${ }^{11}$ ) is increasingly recognised. Even with extensive investigation, a significant number of patients retain the label "idiopathic bronchiectasis". ${ }^{12} 13$

Those with bronchiectasis suffer from recurrent acute exacerbations, some requiring treatment in hospital. ${ }^{14}$ Unless otherwise stated, all data presented are specific to non-CF bronchiectasis. Clinically, major pulmonary symptoms and signs of acute exacerbations in bronchiectasis are similar to that of CF-increased cough and/or wheeze, sputum production, dyspnoea and lethargy. In people with severe exacerbations, especially in the presence of severe bronchiectasis, hypoxaemia may also be present. However, the definition of an acute exacerbation is not standardised, and it has been variably defined to include some or all of the following: increased cough, sputum production/ volume or purulence, dyspnoea, haemoptysis, or deterioration in spirometry, chest signs, radiographic changes. ${ }^{15}{ }^{16}$ Other possible modalities for assessing acute exacerbation are discussed in table 1.
EPIDEMIOLOGY OF EXACERBATIONS

Hospital admissions across time and countries

Hospital admissions for bronchiectasis have decreased with time for both children and adults in affluent countries. ${ }^{7}$ In a Finnish study, new occurrence, admissions and number of days in hospital for bronchiectasis have decreased. ${ }^{7}$ There were 143 and 87 admissions per million inhabitants in 1972 and 1992, respectively. In the period between 1983 and 1992, hospitalisation occurrence was 4.9/million person-years at age 0-14 years, 103.8 at $\geqslant 65$ years and 38.9 in the total population. ${ }^{17}$ Current prevalence data on hospital admissions specifically for bronchiectasis are unavailable, but there is a general impression among respiratory physicians that the prevalence in the young (and, hence, presumably exacerbations and hospital admissions) is increasing. ${ }^{18-20}$ A case-control study in adults matched for age, gender and co-morbidity found that those with bronchiectasis were hospitalised for an additional 2 days/year (95\% confidence interval (CI) 1.7 to 2.3), ${ }^{19}$ and the difference between the groups in the cost of inpatient care was US\$3200/year. In developing countries, hospitalisation for exacerbation of bronchiectasis is still common. $^{8}$

\section{Bronchiectasis as a co-existing illness or co- morbidity}

Bronchiectasis is a common complication of a variety of diseases. When it is present with an underlying disorder, increased morbidity and mortality have been described. ${ }^{8} 1021$ In diseases like COPD, the presence of bronchiectasis is common $^{822}$ in population cohorts and its presence increases the severity ${ }^{8}$ and frequency ${ }^{23}$ of pulmonary exacerbations. In a primary care study, O'Brien and colleagues described the radiological presence of bronchiectasis in $29 \%$ of 110 adults who had mild to severe COPD. ${ }^{22}$ In a hospital-based study $(\mathrm{n}=54), 50 \%$ of adults with moderate to severe COPD had bronchiectasis, and those with bronchiectasis were more likely to have severe exacerbations, airway chronic infection and increased sputum inflammatory markers. ${ }^{8}$ This raises two issues: (1) it is possible that some people may have bronchiectasis as a primary aetiology of airway obstruction rather than COPD; and (2) during an exacerbation, distinguishing an exacerbation of bronchiectasis from a COPD exacerbation can be artificial, especially when the disease is severe.

\section{Sputum and airway markers as risk factors for exacerbations}

The relationship between respiratory infections and bronchiectasis was described decades ago. ${ }^{24}$ 
Table 1 Modalities for monitoring bronchiectasis

\begin{tabular}{|c|c|c|}
\hline Modality & Description & Limitation \\
\hline \multicolumn{3}{|l|}{ Clinical } \\
\hline $\begin{array}{l}\text { Symptoms and } \\
\text { signs }\end{array}$ & $\begin{array}{l}\text { Increased cough, sputum } \\
\text { production/volume or purulence, } \\
\text { dyspnoea, lethargy, haemoptysis, } \\
\text { chest pain }{ }^{70} \text { or deterioration in } \\
\text { chest signs }\end{array}$ & $\begin{array}{l}\text { Perception issues }{ }^{74} \text { and } \\
\text { likely insensitive }\end{array}$ \\
\hline \multicolumn{3}{|l|}{ Lung function } \\
\hline Spirometry & $\begin{array}{l}\text { Classically obstructive, easy } \\
\text { to do and use when aged } \\
>6 \text { years }\end{array}$ & $\begin{array}{l}\text { Insensitive and patients } \\
\text { can have structural airway } \\
\text { changes on HRCT despite } \\
\text { normal spirometry }\end{array}$ \\
\hline $00 \mathrm{~L}$ & $\begin{array}{l}\text { SGRQ validated for } \\
\text { bronchiectasis } \\
\text { in studies }{ }^{99} 6976\end{array}$ & $\begin{array}{l}\text { No bronchiectasis-specific } \\
\text { OOL exists }\end{array}$ \\
\hline \multicolumn{3}{|l|}{ Radiology } \\
\hline Chest radiograph & $\begin{array}{l}\text { Increased markings, lesions, } \\
\text { scarring, atelectasis }{ }^{77}\end{array}$ & Poor sensitivity ${ }^{78}$ \\
\hline HRCT scan & $\begin{array}{l}\text { Many scoring systems for } \\
\text { bronchiectasis exist, }^{79} 8081 \text { "best" } \\
\text { unknown. Exacerbation frequency } \\
\text { related to bronchial wall thickening }\end{array}$ & $\begin{array}{l}\text { Impractical for regular use; } \\
\text { issues with radiation } \\
\text { dose }^{82} \text { especially in } \\
{ }^{8} \text { children }^{83}\end{array}$ \\
\hline \multicolumn{3}{|l|}{$\begin{array}{l}\text { Airway inflammation/ } \\
\text { oxidation }\end{array}$} \\
\hline Exhaled $\mathrm{H}_{2} \mathrm{O}_{2}$ & $\begin{array}{l}\text { Elevated in bronchiectasis, } \\
\text { negative correlation with } \mathrm{FEV}_{1}{ }^{84}\end{array}$ & $\begin{array}{l}\text { More studies required } \\
\text { Steroids have no effect on } \\
\mathrm{H}_{2} \mathrm{O}_{2}\end{array}$ \\
\hline Exhaled CO & Elevated in bronchiectasis ${ }^{85}$ & More studies required \\
\hline Exhaled NO & $\begin{array}{l}\text { Decreased, normal and increased } \\
\text { values described. Correlation } \\
\text { with disease severity if not on } \\
\text { steroids }^{86}\end{array}$ & $\begin{array}{l}\text { Inconsistent data. } \\
\text { Sensitivity unknown, } \\
\text { currently unsuitable as a } \\
\text { monitoring tool for } \\
\text { bronchiectasis. }\end{array}$ \\
\hline Sputum indices & $\begin{array}{l}\text { Airway neutrophilia reduces with } \\
\text { antibiotic treatment, }{ }^{59} \text { tumour } \\
\text { necrosis factor } \alpha, \text { interleukin- } 8, \\
\text { neutrophil elastase also decreases } \\
\text { with antibiotics }{ }^{59}\end{array}$ & $\begin{array}{l}\text { Useful when asthma or } \\
\text { ABPA }^{87} \text { suspected as } \\
\text { cause of exacerbation; eg, } \\
\text { if eosoinophilia present, } \\
\text { systemic corticosteroids } \\
\text { likely to be beneficial }\end{array}$ \\
\hline \multicolumn{3}{|l|}{ AHR } \\
\hline Methacholine & Increased $\mathrm{AHR}^{47}$ & $\begin{array}{l}\text { Direct tests for AHR } \\
\text { increasingly recognised to } \\
\text { be non specific }\end{array}$ \\
\hline Cardiac assessment & $\begin{array}{l}\text { Left ventricular diastolic } \\
\text { dysfunction }{ }^{99} \text { Correlates } \\
\text { with disease severity }\end{array}$ & $\begin{array}{l}\text { No prospective medium/ } \\
\text { long term cohort available } \\
\text { to define role }\end{array}$ \\
\hline Exercise test & $\begin{array}{l}\text { Decreased exercise tolerance, } \\
\text { lower aerobic capacity and } \\
\text { maximal ventilation }\end{array}$ & $\begin{array}{l}\text { No prospective medium/ } \\
\text { long-term cohort available } \\
\text { to define role }\end{array}$ \\
\hline
\end{tabular}

$A B P A$, allergic bronchopulmonary aspergillosis; $A H R$, airway hyper-responsiveness; $\mathrm{CO}$, carbon monoxide; $\mathrm{FEV}_{1}$, forced expiratory volume in $1 \mathrm{~s} ; \mathrm{H}_{2} \mathrm{O}_{2}$, hydrogen peroxide; $\mathrm{HRCT}$, high-resolution computed tomography; NO, nitric oxide; QOL, quality of life; SGRO, St George's respiratory questionnaire

The "role of bacteria in the pathogenesis and progression of acute and chronic lung infection" has been well summarised by Stockley. ${ }^{25}$ Data specific for bronchiectasis exacerbations (as opposed to infections contributing to the pathogenesis of development of bronchiectasis) are less known. Are there any bacteriological or sputum markers that influence exacerbation frequency and/or severity? Hill and colleagues found that adult patients whose purulent sputum became mucoid after treatment had a longer time to next exacerbation (median 6.5 months, range 1-11) than those whose sputum purulence did not clear. ${ }^{26}$ The sputum pathogen isolation/chronic infection rate for paediatric studies varies from $53 \%$ to $67 \%,{ }^{14}$ and that for adult cohorts from $88 \%$ to $100 \%{ }^{12}{ }^{27} 28$ The presence of Pseudomonas aeruginosa is associated with more severe disease in some studies, ${ }^{27} 2930$ but not in one paediatric study. ${ }^{13} P$ aeruginosa occurs less frequently in paediatric cohorts ${ }^{43}$ than in adult cohorts $^{27} 28(0-11 \%$ vs $4-33 \%)$. In the study by Wilson and colleagues, ${ }^{29}$ adults colonised with $P$ aeruginosa were no more likely to have infective exacerbations but were likely to have been hospitalised in the previous year compared with those colonised with Haemophilus influenzae or other bacterial pathogens. There are no similar paediatric data available, and we could not find any prospective study that has examined the effect of $P$ aeruginosa or other pathogen eradication on exacerbation frequency. The presence of increased sputum interleukin (IL)-6 in the stable state is related to increased frequency of exacerbations in adults. ${ }^{8}$

\section{Other risk factors for exacerbations of bronchiectasis}

The frequency of exacerbations is higher in more severe disease ${ }^{31}$ and unmanaged bronchiectasis. ${ }^{1}$ In a Turkish study of 111 children, "intensive medical treatment" (prompt antibiotic use, physiotherapy, bronchodilators) reduced exacerbation rates from a mean (SD) of 6.6 (4.0) to 2.9 (2.9) per year. ${ }^{1}$ There are few other specific data on risks for exacerbations. Factors that can lead to bronchiectasis may theoretically also exacerbate bronchiectasis and include poor nutrition, poverty, environmental factors and some co-existent diseases.

There are no studies on the influence of nutrition on bronchiectasis exacerbations. However, it is known that poor nutrition (macronutrients and micronutrients) affects both innate and adaptive immune function ${ }^{32}$ and childhood morbidity and mortality. ${ }^{33}$ Malnutrition of both macronutrients and some micronutrients increases infection risks as it creates an immune deficient state and leads to the malnutrition/infection/ malnutrition cycle. ${ }^{34}$ Also, evidence from studies on nutrition in other chronic respiratory diseases ${ }^{35}$ supports the clinical observation that poor nutrition is a risk factor for pulmonary exacerbations in people with bronchiectasis.

It has been well documented that increased poverty, ${ }^{36}$ pollution (environmental or occupational ${ }^{37}$ ) tobacco smoke, ${ }^{38}$ biomass combustion ${ }^{39}$ and other public health issues are associated with increased respiratory infections and/or bronchiectasis. Environmental pollutants are well known to exacerbate any chronic respiratory insufficiency. ${ }^{40}$ However, there are no specific studies of the role of the above on bronchiectasis exacerbations.

Bronchiectasis and other forms of suppurative lung disease have been described in individuals with neurological and neuromuscular conditions that reduce the effectiveness of cough. In such cases, the increased risk of aspirating oropharyngeal contents makes oral hygiene important. In a study of 10 children with such conditions, Brook noted that 6 had evidence of poor oral hygiene. ${ }^{41}$ Similar data have been reported in adults with COPD where periodontal disease was associated with more severe airway obstruction. ${ }^{42}$ There are no studies specifically on the effect of oral hygiene on pulmonary exacerbations of bronchiectasis.

People with bronchiectasis have an increased incidence of other co-morbidities such as gastro-oesophageal reflux (GOR) ${ }^{43}$ and "asthma-like" disease. ${ }^{6}$ These would theoretically be a risk factor for exacerbations, but how much these contribute to frequency and/or severity of exacerbations has not been studied. "Asthma-like" disease, present in 21-39\% of bronchiectasis cohorts, ${ }^{44}$ is an independent risk factor for accelerated pulmonary decline in adults ${ }^{21}$ and children. ${ }^{46}$ Increased airway responsiveness is associated with more severe disease. ${ }^{47}$ A study from the Middle East found that patients with bronchiectasis who had an obstructive pattern on spirometric testing were significantly more likely to have an exacerbation requiring 
admission to hospital than those with non-obstructive airways (6 vs 2 hospital admissions, respectively). ${ }^{48}$ These co-existent relationships, however, need to be interpreted with caution; for example, the treatment for GOR only modestly influenced cough $^{49}$ and asthma ${ }^{50}$ outcomes in randomised controlled trials in contrast to cohort studies.

\section{PATHOGENESIS OF EXACERBATIONS}

Triggers of bronchiectasis exacerbations have not been studied. It is commonly assumed that any of the risk factors presented above can trigger an exacerbation, and that a pathogen is always involved at some point of the exacerbation. In Cole's "vicious circle hypothesis" the pathogenesis of bronchiectasis includes an initial insult to the lower airways, impaired mucociliary clearance, microbial colonisation/infection, bronchial obstruction and a normal or exaggerated inflammatory response. ${ }^{51}$ There is indirect support for Cole's model.

Persistent inflammation plays a role in deterioration of lung function $^{25}$ in bronchiectasis. ${ }^{52}$ The airways of adults with bronchiectasis have increased pro-inflammatory mediators; endobronchial biopsy specimens from adults with bronchiectasis who are clinically stable have increased neutrophil matrix metalloproteinases- 8 and $-9 .{ }^{53}$ Their bronchoalveolar lavage fluid contains increased levels of neutrophils, elastase, myeloperoxidase, tumour necrosis factor (TNF) $\alpha$, interleukin (IL)-8 and IL-6 compared with controls. ${ }^{54}$ Serum levels of adhesion molecules Eselectin, intercellular adhesion molecule- 1 and vascular adhesion molecule- 1 are also raised, with the former two inversely related to forced expiratory volume in $1 \mathrm{~s}\left(\mathrm{FEV}_{1}\right){ }^{55}$ Those with more severe bronchiectasis (earlier diagnosis, lower $\mathrm{FEV}_{1}$ and varicosecystic bronchiectasis) are more likely to be colonised with pathogens ${ }^{56}$ and have more intense inflammation than those not colonised. ${ }^{54}$ Sputum purulence increases during exacerbations and decreases with treatment for exacerbation. ${ }^{26}$ Those with less purulent sputum in the non-acute state have a longer period before the next exacerbation. ${ }^{26}$ Several groups have shown an alteration in neutrophilic inflammatory profiles after antibiotic treatment. ${ }^{57} 58$ In the study reported by Ip and colleagues, ${ }^{57}$ patients with acute exacerbations of bronchiectasis treated with oral antibiotics had increased sputum neutrophil chemotactic activity and elastolytic activity during an exacerbation. Watt and colleagues ${ }^{59}$ also showed that concentrations of TNF $\alpha$, IL-8 and neutrophil elastase in sputum supernatant were significantly reduced at day 14 of antibiotics compared with initiation of treatment. Lung permeability decreased in two of the six patients whose sputum was cleared of pathogens following treatment with antibiotics. ${ }^{60}$

The above data therefore suggest that airway infection and inflammation are important during an exacerbation. However, it is unknown what proportion of bronchiectasis exacerbations are triggered by an infection and, if so, the type of infection. It is also unknown how often viral infections trigger an exacerbation. Klingman and colleagues ${ }^{61}$ prospectively performed bimonthly sputum cultures as well as during an exacerbation in 28 adults. They found that a subset of six patients was repeatedly colonised with Moraxella catarrhalis but there was no relationship between the viable numbers of bacteria recovered and the exacerbation or clinical status, although antibiotic therapy resulted in reduced viable bacterial numbers at the end of the treatment. During the total of 18 exacerbations, the pattern of $M$ catarrhalis cultured was inconsistent.

Based on their findings that adults treated with ciprofloxacin had a better clinical outcome than those treated with amoxicillin, Chan and colleagues ${ }^{62}$ suggested that $P$ aeruginosa is an important pathogen during an infective exacerbation. Mycobacteria have been reported as a common cause of exacerbations ${ }^{63}$ and as a cause of pulmonary deterioration. ${ }^{64}$ The Hong Kong series reported the presence of non-tuberculous mycobacteria (NTM) in $13 \%$ of 91 adults $^{63}$ whereas the London series reported NTM in $2 \%$ of their prospective study of 100 patients. ${ }^{64}$ Fungal infection and allergic bronchopulmonary aspergillosis, which can itself cause bronchiectasis, have also been implicated in case studies. ${ }^{65}$ In the absence of adequate double-blind placebo-controlled randomised trials and good prospective data, the role of these particular organisms in acute exacerbations remains unclear.

Patients may remain colonised with the same microbiological species both in the stable state and during acute exacerbations. The possible triggers for the exacerbation in that setting include viral infection or infection with a new bacteria or a change in bacterial strain with associated variability in bacterial epitopes important for immune recognition. Alternatively, there may simply be rapid multiplication of the existing colonising species or "planktonic bloom" in the case of $P$ aeruginosa in CF. ${ }^{66}$

\section{PREVENTION OF ACUTE EXACERBATIONS}

In people with diseases which predispose to the development of bronchiectasis (such as primary ciliary dyskinesia and primary immunodeficiency), prevention of the development of bronchiectasis through modalities that prevent or limit respiratory infections is a long-term management goal. ${ }^{67} 68$ Ellerman and Bisgaard $^{67}$ showed, in their cohort of people with primary ciliary dyskinesia, that adults who were diagnosed later had significantly poorer lung function. They concluded that progressive deterioration in lung function occurs with inadequate treatment of symptoms and that lung function can be maintained with appropriate antibiotic treatment and regular physiotherapy. This further supports Cole's vicious cycle hypothesis ${ }^{51}$ that further or ongoing infection and resultant inflammation can lead to further lung destruction. Thus, prevention of recurrent exacerbations is important for maintenance of lung function. Also, exacerbations have a negative impact on quality of life issues and healthcare costs. ${ }^{14} 1719$ Strongest predictors of quality of life in clinically stable bronchiectasis include dyspnoea, $\mathrm{FEV}_{1}$ and sputum production. ${ }^{69}$ In an exacerbation where all three factors are generally worse, ${ }^{70}$ quality of life would decrease. Furthermore, Wilson et al demonstrated a clear relationship between lower quality of life in the St George's questionnaire and increasing numbers of exacerbations. ${ }^{71}$

In many diseases the prevention of acute exacerbations is linked to early recognition and close monitoring of disease activity/ severity. ${ }^{72}$ These are less defined in bronchiectasis than in diseases such as asthma. Current available modalities and their limitations are presented in table 1. Most of the studies were performed during the stable phase and most — but not all — studies showed increased dysfunction with decreasing pulmonary function. Thus, while some may be considered as markers of disease severity and possibly reflective of exacerbations, more research is required and the clinical utility of these tests remains undefined.

\section{Modalities for prevention of exacerbations}

\section{General}

It is generally accepted that earlier diagnosis, close monitoring and intensive therapy reduces the frequency and/or severity of exacerbations and slows pulmonary decline. ${ }^{167}$ However, there is limited published evidence. In 101 children with bronchiectasis Li et $a l^{13}$ found that determination of the underlying aetiology of 
Table 2 Treatments for prevention of exacerbations

\begin{tabular}{|c|c|c|c|}
\hline & Evidence type/study & Summary of results & Notes \\
\hline \multicolumn{4}{|l|}{ Antimicrobial agents } \\
\hline General & Cochrane review, $^{99}$ other systematic review ${ }^{93}$ & Generally beneficial (see text) & $\begin{array}{l}\text { Resistance and nebulised tobramycin } \\
\text { poorly tolerated in some }\end{array}$ \\
\hline Nebulised tobramycin $^{94}$ & $\begin{array}{l}\text { Double blind crossover RCT in } 30 \text { patients with } \\
P \text { aeruginosa, } 6 \text { months each }\end{array}$ & $\begin{array}{l}\text { Number and days of admissions less in } \\
\text { tobramycin arm but no difference in } \\
\text { number of exacerbations }\end{array}$ & $\begin{array}{l}\text { Resistance and nebulised tobramycin } \\
\text { poorly tolerated in some }\end{array}$ \\
\hline \multicolumn{4}{|l|}{ Anti-inflammatory agents } \\
\hline Indomethacin ${ }^{100}$ & $\begin{array}{l}\text { Cohort study, } 25 \mathrm{mg} \text { three times daily for } \\
28 \text { days }\end{array}$ & $\begin{array}{l}\text { Reduction in peripheral neutrophil } \\
\text { chemotaxis; no change in sputum albumin, } \\
\text { elastase, myeloperoxidase or exacerbation }\end{array}$ & \\
\hline \multicolumn{4}{|l|}{ Mucolytics } \\
\hline Bromhexine & Cochrane review ${ }^{101}$ & Studies only in acute phase & Not universally available \\
\hline rhDNAse & Systematic review ${ }^{101} 102$ & Increased exacerbation rate & \\
\hline \multicolumn{4}{|l|}{ Asthma therapies } \\
\hline Inhaled corticosteroids (ICS) & $\begin{array}{l}\text { Cochrane review }{ }^{104} \text { and double blind RCT } \\
\text { using } 500 \mu \mathrm{g} \text { fluticasone twice daily }\end{array}$ & $\begin{array}{l}\text { Reduced exacerbation rate only seen in } \\
\text { those with } P \text { aeruginosa infection. } .^{15} \text { No } \\
\text { significant effect of ICS in Cochrane } \\
\text { review }^{104}\end{array}$ & $\begin{array}{l}\text { Limited applicability in children-high dose } \\
\text { ICS and children less likely to have } P \\
\text { aeruginosa }\end{array}$ \\
\hline Oral corticosteroids & Cochrane review ${ }^{106}$ & No RCTs & No data* \\
\hline Anticholinergics & Cochrane review ${ }^{107}$ & No RCTs & No data* \\
\hline$\beta_{2}$-agonists & Cochrane review ${ }^{108} 109$ & No RCTs & No data* \\
\hline LTRA & Cochrane review ${ }^{110}$ & No RCTs & No data* \\
\hline Physical training & $\begin{array}{l}\text { Cochrane review }{ }^{111} \text { and } \mathrm{RCT}^{112} \text { which was } \\
\text { included in Cochrane as an abstract } \\
\text { (data changed) }\end{array}$ & No data on exacerbation & $\begin{array}{l}\text { Pulmonary rehabilitation improves exercise } \\
\text { tolerance, no additional advantage of } \\
\text { simultaneous inspiratory muscle training }\end{array}$ \\
\hline \multicolumn{4}{|l|}{ Ventilatory assistance } \\
\hline \multirow[t]{2}{*}{ NPPV $\dagger$} & $\begin{array}{l}\text { Retrospective case controlled study on } \\
\text { NPPV with oxygen } 20\end{array}$ & $\begin{array}{l}\text { Reduced hospitalisation rate, no } \\
\text { difference in mortality }\end{array}$ & No effect on survival \\
\hline & $\begin{array}{l}\text { Retrospective study using NPPV with } \\
\text { oxygen }^{121}\end{array}$ & $\begin{array}{l}\text { Reduced hospitalisation days, improved } \\
\text { QOL }\end{array}$ & $\begin{array}{l}\mathrm{PaCO}_{2} \text { stabilised after NIV but no change on } \\
\mathrm{PaO}_{2}\end{array}$ \\
\hline \multicolumn{4}{|l|}{ Model of care } \\
\hline Nurse-led & Cochrane review ${ }^{122}$ & $\begin{array}{l}\text { No difference in infective exacerbations } \\
\text { but increase in hospitalisations in } \\
\text { nurse-led care compared with } \\
\text { doctor-led care }\end{array}$ & Increased healthcare cost implications \\
\hline Sputum surveillance & No data* & $\begin{array}{l}\text { Suggestions that this should be done }{ }^{123} \\
\text { (frequency undefined) }\end{array}$ & $\begin{array}{l}\text { Chronic infection or colonisation prevalent } \\
\text { (see text) }\end{array}$ \\
\hline Psychosocial & No data* & & $34 \%$ have depression, anxiety or both ${ }^{74}$ \\
\hline
\end{tabular}

COPD, chronic obstructive pulmonary disease; HS, hypertonic saline; LTRA, leucotriene receptor antagonist; NPPV, non-invasive positive pressure ventilation; 00L, quality of life; $\mathrm{RCT}$, randomised controlled trial.

*No other data specific to exacerbation based on single reviewer search on PubMed (March 2006).

$\dagger$ A review article suggested that non-invasive positive pressure ventilation is probably beneficial in reducing exacerbation days/episodes in those with chronic respiratory failure, although the data are scarce. ${ }^{113}$

bronchiectasis can lead to distinct and individualised change in management; subsequent exacerbation frequency or severity was not determined in the study but, based on other data, appropriate therapy improves prognosis ${ }^{67}$ which is associated with reduced exacerbations. ${ }^{1}$ Exacerbation frequency per year is directly related to bronchial wall thickening on high-resolution computed tomographic (HRCT) chest scans, ${ }^{31}$ and severe bronchial wall thickness was the most adverse prognostic determinant in a study using serial chest HRCT scans. ${ }^{92}$

Antimicrobial agents

The systematic review by Yang and colleagues ${ }^{93}$ (search date March 2003) described six studies on antibiotics used in the 
Table 3 Treatments for acute exacerbations of bronchiectasis

\begin{tabular}{|c|c|c|c|}
\hline & Evidence or study & Summary data & Limitations \\
\hline Antimicrobial agents & Systematic review ${ }^{93}$ & Beneficial (see text) & \\
\hline Anti-inflammatories & ${ }^{*}$ No data & & \\
\hline \multicolumn{4}{|l|}{ Mucolytics } \\
\hline rhDNase & Systematic review ${ }^{101} 102$ & $\begin{array}{l}\text { No studies in acute phase. } .^{101} 102 \text { Note increased } \\
\text { exacerbation rate when used in non-acute phase }\end{array}$ & $\begin{array}{l}\text { Adverse effects more common in } \\
\text { the group receiving rhDNase }\end{array}$ \\
\hline Chest physiotherapy & Cochrane review ${ }^{103}$ & No data* & \\
\hline Inhaled hyperosmolar agents & Cochrane review ${ }^{104} 105$ & $\begin{array}{l}\text { One RCT using single mannitol dose in stable } \\
\text { bronchiectasis, }{ }^{127} \text { improved airway clearance; one } \\
\text { study on } 7 \% \text { HS as adjunct to physiotherapy. }{ }^{105} \\
\text { Sputum weights, ease for expectoration, viscosity } \\
\text { better in HS group }\end{array}$ & \\
\hline \multicolumn{4}{|l|}{ Asthma therapies } \\
\hline LTRA & Cochrane review ${ }^{110}$ & No RCTs & No other data* \\
\hline Methylxanthines & Cochrane review ${ }^{128}$ & No RCTs & No other data* \\
\hline Exercise/physical training & No data* & & \\
\hline Oxygen & No data* & Consider data from COPD & \\
\hline Surgery & No data* & & \\
\hline \multicolumn{4}{|l|}{ Ventilatory assistance } \\
\hline BTS guidelines ${ }^{126}$ & See text & & \\
\hline
\end{tabular}

HS, hypertonic saline; LTRA, leucotriene receptor antagonist; RCT, randomised controlled trial; rhDNase, recombinant human deoxyribonuclease.

${ }^{*}$ No other data specific to acute exacerbation management based on single reviewer search (up to March 2006).

stable phase; only five of these trials used antibiotics for $\geqslant 4$ weeks and, of these, two used antibiotics for $\geqslant 6$ months. The MRC 1957 study compared the prolonged use of either oxytetracycline or penicillin with placebo over 12 months. Oxytetracycline was more effective than penicillin or placebo in reducing $24 \mathrm{~h}$ sputum volume, cough, dyspnoea and days confined to bed. ${ }^{93}$ A trial of 38 patients randomised to either amoxicillin or placebo for 32 weeks showed improvement in the amoxicillin group with a reduction in the severity of exacerbations. ${ }^{93}$ We found three further studies ${ }^{169495}$ subsequent to the search date above. Two of the three studies ${ }^{16} 94$ examined for exacerbations (table 2). Exacerbation frequency was reduced in the azithromycin study ${ }^{16}$ but not in the inhaled tobramycin study. ${ }^{94}$ A non-placebo 12 -month trial in non-CF adult patients with chronic Pseudomonas infection showed a reduced number of hospitalisations and days of admission (mean (SE) 0.6 (1.5) vs 13.1 (34.8) days) in those on continuous treatment with either inhaled ceftazidime or tobramycin compared with those receiving symptomatic treatment (ie, treatment only when symptomatic (2.5 (2.1) and 57.9 (41.8)). ${ }^{96}$ The sole randomised controlled trial of $>4$ weeks in childhood bronchiectasis did not examine the exacerbation rate. ${ }^{97}$ In a study by Koh and colleagues, ${ }^{97} 25$ children were randomised to receive 12 weeks of roxithromycin (4 mg/ $\mathrm{kg}$ twice a day) or placebo. A significant improvement in sputum purulence and leucocyte scores and airway hyper-responsiveness but not $\mathrm{FEV}_{1}$ occurred in the roxithromycin group. A Cochrane review on the use of prolonged antibiotics for purulent bronchiectasis in both children and adults also found that, although the use of prolonged antibiotics conferred a small benefit, particularly in terms of sputum characteristics, exacerbation rates were similar between the antibiotic and placebo arms. ${ }^{98}$ Thus, current data suggest that maintenance antibiotics are likely to be beneficial in preventing the frequency and/or the severity of exacerbations, at least in some patients. However, long-term intervention trials have not been conducted in either adults or children with bronchiectasis and further studies are required before this can be recommended for all patients.

There are even fewer data on modalities other than antibiotics for preventing exacerbations, as summarised in table 2. The table and this review do not include specific therapies for underlying aetiologies such as primary immune deficiency; in these circumstances specific therapies such as regular immunoglobulin infusions in hypogammaglobulinaemia reduce pulmonary exacerbations. ${ }^{68}$

\section{TREATMENT OF ACUTE EXACERBATIONS}

There is a glaring lack of studies on the treatment of acute exacerbations, and those available are often insufficiently powered. Thus the "lack of evidence" as opposed to "evidence for lack of effect" is highly relevant for this subject. Management of bronchiectasis has largely been extrapolated from data on CF. While extrapolation appears reasonable for some treatments such as use of antibiotics and chest physiotherapy, it would seem less reasonable for other treatments as the rheology, sputum and electrolyte contents of CF sputum differ from that of non-CF sputum. Indeed, harm has been shown in adults randomised to receive rhDNase compared with placebo, ${ }^{101}$ which is in contrast to the beneficial effect of rhDNase for CF. ${ }^{124}$ In a double-blind, randomised, placebocontrolled, multicentre study for 24 weeks in 349 adults with bronchiectasis, those given rhDNase had a higher exacerbation rate and hospitalisation rate (relative risk 1.35 and 1.85, respectively) and more rapid pulmonary decline (decrease in $\mathrm{FEV}_{1} 3.6 \%$ in rhDNase group, $1.6 \%$ in placebo group). ${ }^{125}$ 
Irrespective of the evidence, the current standard therapy for acute exacerbations is primarily targeted at prolonged antimicrobials and airway clearance techniques. Studies on bacterial chronic infection suggest that empirical antibiotic coverage for exacerbations in adults should include $H$ influenzae and $P$ aeruginosa. ${ }^{28}$ The systematic review by Yang and colleagues (search date March 2003) for adults stated: “... in clinical practice, exacerbations respond well to broad-spectrum antibiotics effective against $P$ aeruginosa, $H$ influenzae and $S$ aureus in conventional doses". ${ }^{93}$ They also examined the question: "which antibiotics work in acute exacerbations of bronchiectasis?" and concludeded that there are "no published RCTs comparing antibiotics with placebo in acute exacerbations of bronchiectasis". ${ }^{33}$ Only four studies were performed in an acute exacerbation and all studies compared quinolones with $\beta$-lactam drugs for 7-10 days. ${ }^{93}$ Quinolones were generally superior, but their long-term use should be considered cautiously because of the risk of antibiotic resistance. Since the review, a further search (March 2006, done by single reviewer) found no further studies relevant to treatment for acute exacerbations.

Management of acute exacerbations includes a search for any treatable trigger factor (discussed above). A summary of the data on the various options for treating acute exacerbations are presented in table 3. In severe and selective situations, oxygen therapy and, rarely, ventilatory assistance are also used. The British Thoracic Society (BTS) guidelines state: "A trial of noninvasive ventilation may be undertaken in patients with a respiratory acidosis ( $\mathrm{pH}<7.35, \mathrm{H}^{+}>45 \mathrm{nmol} / \mathrm{l}$ ) secondary to an acute exacerbation of bronchiectasis, but excessive secretions are likely to limit its effectiveness and it should not be used routinely in bronchiectasis". ${ }^{126}$ The survival of patients with bronchiectasis after the first ICU stay for respiratory failure is poor; 19\% died during their ICU stay and 1-year mortality was $40 \%$ (risk was particularly increased in older (>65 years) patients and those on long term oxygen). ${ }^{118}$

\section{Clinical and research questions}

Research into the prevention and treatment of exacerbations of bronchiectasis requires an international consensus on the definition of an exacerbation which is validated against sputum or breath inflammatory markers, as well as clinical and spirometric parameters. Once we have a well validated definition, the investigation of the triggers and causes of exacerbations can be studied. It will be particularly helpful in determining the effect of viruses in this setting, and in elucidating the variability of bacterial strains and their contribution to exacerbations in bronchiectasis.

The validation of end points for studies of exacerbation treatments is a further obstacle to the conduct of large randomised controlled trials. While clinicians recognise the parameters of sputum volume and colour as key clinical indicators of successful treatment in non-CF bronchiectasis, these have not been validated sufficiently to be acceptable end points to regulatory bodies. This is particularly important as $\mathrm{FEV}_{1}$ is a less sensitive measure in acute exacerbations of bronchiectasis (in contrast to $\mathrm{CF}$ ). The measurement of small airways function is worthy of further investigation and validation in this setting.

It is critical that, in all these areas, studies are performed in both children and adults in sufficient numbers to identify similarities and differences in treatment effects. Randomised controlled trials are required to assess the benefits of adjunctive therapies during acute exacerbations. We have no information currently, for example, on the risks and benefits of the addition of oral steroids during an acute exacerbation. Finally, at the most simple level, our current antibiotic treatments for acute exacerbations still require rigorous assessment. We do not know the optimal duration of antibiotic therapy for acute exacerbations-not only in terms of optimum short-term benefit but, importantly, in terms of delaying the time to next exacerbation. Future trials of treatment in acute exacerbations must include sufficient follow-up to assess the time to next exacerbation, which is an emerging clinical trial end point in studies of patients with CF. ${ }^{129}$

\section{CONCLUSIONS}

Acute pulmonary exacerbations are now recognised as an important outcome measure in bronchiectasis, just as they are in other respiratory diseases such as $\mathrm{COPD},{ }^{73} \mathrm{CF}$ and asthma. Exacerbations have a significant impact on quality of life, acutely reduce respiratory function, result in hospitalisations and are a likely contributor to long-term respiratory decline. However, contributors to these exacerbations are poorly understood and evidence-based care for the prevention and management of exacerbations is scarce. Future clinical and research challenges include the ability to better define and monitor exacerbations, understanding the causes of exacerbations, monitoring of disease and improved management of exacerbations.

Acknowledgements: The authors thank Associate Professor Scott Bell for his input, provision of several references and critique of the manuscript, and Dr Margaret McElrea for her critique of the manuscript.

Funding: $A B C$ is funded by the Australian National Health Medical Research Council and the Royal Children's Hospital Foundation.

Competing interests: None.

\section{REFERENCES}

1. Karadag B, Karakoc F, Ersu R, et al. Non-cystic-fibrosis bronchiectasis in children: a persisting problem in developing countries. Respiration 2005;72:233-8.

2. Karakoc GB, Yilmaz M, Altintas DU, et al. Bronchiectasis: still a problem. Pediatr Pulmonol 2001;32:175-8.

3. Callahan CW, Redding GJ. Bronchiectasis in children: orphan disease or persistent problem? Pediatr Pulmonol 2002;33:492-6.

4. Edwards EA, Asher MI, Byrnes CA. Paediatric bronchiectasis in the twenty-first century: experience of a tertiary children's hospital in New Zealand. J Paediatr Child Health 2003;39:111-7.

5. Chang AB, Grimwood K, Mulholland EK, et al. Bronchiectasis in Indigenous children in remote Australian communities. Med J Aust 2002;177:200-4.

6. Singleton RJ, Morris A, Redding G, et al. Bronchiectasis in Alaska native children: causes and clinical courses. Pediatr Pulmonol 2000;29:182-7.

7. Saynajakangas $\mathbf{0}$, Keistinen T, Tuuponen T, et al. Bronchiectasis in Finland: trends in hospital treatment. Respir Med 1997;91:395-8.

8. Patel IS, Vlahos I, Wilkinson TM, et al. Bronchiectasis, exacerbation indices, and inflammation in chronic obstructive pulmonary disease. Am J Respir Crit Care Med 2004;170:400-7.

9. Chang AB, Masel JP, Masters B. Post-infectious bronchiolitis obliterans: clinical, radiological and pulmonary function sequelae. Pediatr Radiol 1998;28:23-9.

10. Lewis MM, Mortelliti MP, Yeager $\mathrm{H} \mathrm{Jr}$, et al. Clinical bronchiectasis complicating pulmonary sarcoidosis: case series of seven patients. Sarcoidosis Vasc Diffuse Lung Dis 2002;19:154-9.

11. Zrour SH, Touzi M, Bejia I, et al. Correlations between high-resolution computed tomography of the chest and clinical function in patients with rheumatoid arthritis. Prospective study in 75 patients. Joint Bone Spine 2005;72:41-7.

12. Pasteur MC, Helliwell SM, Houghton SJ, et al. An investigation into causative factors in patients with bronchiectasis. Am J Respir Crit Care Med 2000;162:127784.

13. Li AM, Sonnappa S, Lex C, et al. Non-CF bronchiectasis: does knowing the aetiology lead to changes in management? Eur Respir J 2005;26:8-14.

14. Saynajakangas $\mathbf{0}$, Keistinen T, Tuuponen T, et al. The course of childhood bronchiectasis: a case report and considerations of hospital use. Int J Circumpolar Health 1998;57:276-9.

15. Tsang KW, Tan KC, Ho PL, et al. Inhaled fluticasone in bronchiectasis: a 12 month study. Thorax 2005;60:239-43.

16. Cymbala AA, Edmonds LC, Bauer MA, et al. The disease-modifying effects of twice-weekly oral azithromycin in patients with bronchiectasis. Treat Respir Med 2005; 4:117-22. 
17. Saynajakangas $\mathbf{0}$, Keistinen T, Tuuponen T, et al. Evaluation of the incidence and age distribution of bronchiectasis from the Finnish hospital discharge register. Cent Eur J Public Health 1998;6:235-7.

18. Town GI,Crane J. Respiratory health and lung research in New Zealand. Chron Respir Dis 2006;3:167-9.

19. Weycker D, Edelsberg J, Oster G, et al. Prevalence and economic burden of bronchiectasis. Clin Pulm Med 2005;12:205-9.

20. King P, Holdsworth S, Freezer N, et al. Bronchiectasis. Intern Med J 2006;36:72937.

21. Keistinen T, Saynajakangas 0, Tuuponen T, et al. Bronchiectasis: an orphan disease with a poorly-understood prognosis. Eur Respir J 1997;10:2784-7.

22. O'Brien C, Guest PJ, Hill SL, et al. Physiological and radiological characterisation of patients diagnosed with chronic obstructive pulmonary disease in primary care. Thorax 2000;55:635-42.

23. Gursel G. Does coexistence with bronchiectasis influence intensive care unit outcome in patients with chronic obstructive pulmonary disease? Heart Lung 2006:35:58-65.

24. Cherniack NS, Dowling HF, Carton RW, et al. The role of acute lower respiratory infection in causing pulmonary insufficiency in bronchiectasis. Ann Intern Med 1967:66:489-97.

25. Stockley RA. Role of bacteria in the pathogenesis and progression of acute and chronic lung infection. Thorax 1998;53:58-62.

26. Hill SL, Morrison HM, Burnett D, et al. Short term response of patients with bronchiectasis to treatment with amoxycillin given in standard or high doses orally or by inhalation. Thorax 1986;41:559-65.

27. Ho PL, Chan KN, Ip MS, et al. The effect of Pseudomonas aeruginosa infection on clinical parameters in steady-state bronchiectasis. Chest 1998;114:1594-8.

28. Cabello H, Torres A, Celis R, et al. Bacterial colonization of distal airways in healthy subjects and chronic lung disease: a bronchoscopic study. Eur Respir J 1997; 10:1137-44.

29. Wilson CB, Jones PW, O'Leary CJ, et al. Effect of sputum bacteriology on the quality of life of patients with bronchiectasis. Eur Respir J 1997;10:1754-60.

30. Evans SA, Turner SM, Bosch BJ, et al. Lung function in bronchiectasis: the influence of Pseudomonas aeruginosa. Eur Respir J 1996:9:1601-4.

31. Ooi GC, Khong PL, Chan-Yeung M, et al. High-resolution CT quantification of bronchiectasis: clinical and functional correlation. Radiology 2002;225:663-72.

32. Failla ML. Trace elements and host defense: recent advances and continuing challenges. J Nutr 2003;133:1443-7S.

33. Fatmi Z, White F. A comparison of 'cough and cold' and pneumonia: risk factors for pneumonia in children under 5 years revisited. Int J Infect Dis 2002;6:294-301.

34. Gracey M. Nutrition and infections in Australian aboriginal children. Aust NZ J Med 1991;21:921-7.

35. Katsura H, Ogata M, Kida K. Factors determining outcome in elderly patients with severe COPD on long-term domiciliary oxygen therapy. Monaldi Arch Chest Dis 2001:56:195-201.

36. Hatt LE, Waters HR. Determinants of child morbidity in Latin America: a pooled analysis of interactions between parental education and economic status. Soc Sci Med 2006;62:375-86.

37. Altin R, Savranlar A, Kart L, et al. Presence and HRCT quantification of bronchiectasis in coal workers. Eur J Radiol 2004;52:157-63.

38. Li JS, Peat JK, Xuan W, et al. Meta-analysis on the association between environmental tobacco smoke (ETS) exposure and the prevalence of lower respiratory tract infection in early childhood. Pediatr Pulmonol 1999;27:5-13.

39. Ezzati M, Kammen D. Indoor air pollution from biomass combustion and acute respiratory infections in Kenya: an exposure-response study. Lancet 2001;358:61924

40. Utell MJ, Frampton MW. Acute health effects of ambient air pollution: the ultrafine particle hypothesis. J Aerosol Med 2000;13:355-9.

41. Brook I, Finegold SM. Bacteriology and therapy of lung abscess in children. J Pediatr 1979;94:10-2

42. Scannapieco FA, Ho AW. Potential associates between chronic respiratory disease and periodontal disease: analysis of National Health and Nutrition Examination Survey III. J Periodontol 2001;72:50-6.

43. Tsang KW, Lam WK, Kwok E, et al. Helicobacter pylori and upper gastrointestinal symptoms in bronchiectasis. Eur Respir J 1999;14:1345-50.

44. Twiss J, Stewart AW, Byrnes CA. Longitudinal pulmonary function of childhood bronchiectasis and comparison with cystic fibrosis. Thorax 2006;61:414-8.

45. Chang AB, Masel JP, Boyce NC, et al. Non-CF bronchiectasis-clinical and HRCT evaluation. Pediatr Pulmonol 2003;35:477-83.

46. Field CE. Bronchiectasis: Third report on a follow-up study of medical and surgical cases from childhood. Arch Dis Child 1969:44:551-61.

47. Bahous J, Cartier A, Pneau L, et al. Pulmonary function tests and airway responsiveness to methacholine in chronic bronchiectasis of the adult. Bull Eur Physiopathol Respir 1984;20:375-80

48. Khalid M, Saleemi S, Zeitouni M, et al. Effect of obstructive airway disease in patients with non-cystic fibrosis bronchiectasis. Ann Saudi Med 2004;24:284-7.

49. Chang AB, Lasserson TJ, Kiljander TO, et al. Systematic review and meta-analysis of randomised controlled trials of gastro-oesophageal reflux interventions for chronic cough associated with gastro-oesophageal reflux. BMJ 2006;332:11-7.

50. Gibson PG, Henry R, Coughlan J. Gastro-oesophageal reflux treatment for asthma in adults and children. Cochrane Database Syst Rev 2003;(1).

51. Cole PJ. Inflammation: a two edged sword. The model of bronchiectasis. Eur J Respir Dis Supp/ 1986;147:6-15.
52. Ip $\mathbf{M}$, Lauder IJ, Wong WY, et al. Multivariate analysis of factors affecting pulmonary function in bronchiectasis. Respiration 1993;60:45-50.

53. Zheng L, Lam WK, Tipoe GL, et al. Overexpression of matrix metalloproteinase-8 and -9 in bronchiectatic airways in vivo. Eur Respir $\mathrm{J} 2002 ; 20: 170-6$.

54. Angrill J, Agusti C, de Celis R, et al. Bronchial inflammation and colonization in patients with clinically stable bronchiectasis. Am J Respir Crit Care Med 2001:164:1628-32.

55. Zheng L, Tipoe G, Lam WK, et al. Up-regulation of circulating adhesion molecules in bronchiectasis. Eur Respir J 2000;16:691-6.

56. Angrill J, Agusti C, de Celis R, et al. Bacterial colonisation in patients with bronchiectasis: microbiological pattern and risk factors. Thorax 2002;57:15-9.

57. Ip M, Shum D, Lauder I, et al. Effect of antibiotics on sputum inflammatory contents in acute exacerbations of bronchiectasis. Respir Med 1993;87:449-54.

58. Lin HC, Cheng HF, Wang $\mathrm{CH}$, et al. Inhaled gentamicin reduces airway neutrophil activity and mucus secretion in bronchiectasis. Am J Respir Crit Care Med 1997; 155:2024-9

59. Watt AP, Brown V, Courtney J, et al. Neutrophil apoptosis, proinflammatory mediators and cell counts in bronchiectasis. Thorax 2004;59:231-6.

60. Chan TB, Arm JP, Anderson J, et al. Pulmonary epithelial permeability in bronchiectasis. Br J Dis Chest 1988;82:56-63.

61. Klingman KL, Pye A, Murphy TF, et al. Dynamics of respiratory tract colonization by Branhamella catarrhalis in bronchiectasis. Am J Respir Crit Care Med 1995; 152:1072-8

62. Chan TH, Ho SS, Lai CK, et al. Comparison of oral ciprofloxacin and amoxycillin in treating infective exacerbations of bronchiectasis in Hong Kong. Chemotherapy 1996;42:150-6.

63. Chan $\mathbf{C H}, \mathrm{Ho}$ AK, Chan $\mathrm{RC}$, et al. Mycobacteria as a cause of infective exacerbation in bronchiectasis. Postgrad Med J 1992;68:896-9.

64. Wickremasinghe M, Ozerovitch LJ, Davies G, et al. Non-tuberculous mycobacteria in patients with bronchiectasis. Thorax 2005;60:1045-51.

65. Judson MA. Noninvasive Aspergillus pulmonary disease. Semin Respir Crit Care Med 2004;25:203-19.

66. Van Devanter DR, Van Dalfsen JM. How much do Pseudomonas biofilms contribute to symptoms of pulmonary exacerbation in cystic fibrosis? Pediatr Pulmonol 2005;39:504-6.

67. Ellerman A, Bisgaard $\mathrm{H}$. Longitudinal study of lung function in a cohort of primary ciliary dyskinesia. Eur Respir J 1997;10:2376-9.

68. Martinez Garcia MA, de R, Nauffal M, et al. Respiratory disorders in common variable immunodeficiency. Respir Med 2001;95:191-5.

69. Martinez-Garcia MA, Perpina-Tordera M, Roman-Sanchez $P$, et al. Quality-of-life determinants in patients with clinically stable bronchiectasis. Chest 2005;128:73945 .

70. Munro NC, Currie DC, Garbett ND, et al. Chest pain in chronic sputum production: neglected symptom. Respir Med 1989;83:339-41.

71. Wilson CB, Jones PW, O'Leary CJ, et al. Validation of the St George's Respiratory Questionnaire in bronchiectasis. Am J Respir Crit Care Med 1997;156:536-41.

72. FitzGerald JM, Gibson PG. Asthma exacerbations. 4: Prevention. Thorax 2006;61:992-9.

73. Donaldson GC, Wedzicha JA. COPD exacerbations. 1: Epidemiology. Thorax 2006;61:164-8.

74. O'Leary CJ, Wilson CB, Hansell DM, et al. Relationship between psychological wellbeing and lung health status in patients with bronchiectasis. Respir Med 2002:96:686-92.

75. Marchant JM, Masel JP, Dickinson FL, et al. Application of chest high-resolution computer tomography in young children with cystic fibrosis. Pediatr Pulmonol 2001;31:24-9.

76. Chan SL, Chan-Yeung MM, Ooi GC, et al. Validation of the Hong Kong Chinese version of the St. George Respiratory Questionnaire in patients with bronchiectasis. Chest 2002;122:2030-7.

77. Nicotra MB. Bronchiectasis. Semin Respir Infect 1994;9:31-40.

78. Currie DC, Cooke JC, Morgan AD, et al. Interpretation of bronchograms and ches radiographs in patients with chronic sputum production. Thorax 1987;42:278-84.

79. Reiff DB, Wells AU, Carr DH, et al. CT findings in bronchiectasis: limited value in distinguishing between idiopathic and specific types. AJR Am J Roentgenol 1995; 165:261-7.

80. Webb WR, Muller NL, Naidich DP. Airway diseases. In: High-resolution CT of the lung. Philadelphia: Lippincott, Williams and Wilkins, 2001;3:467-546.

81. Roberts HR, Wells AU, Milne DG, et al. Airflow obstruction in bronchiectasis: correlation between computed tomography features and pulmonary function tests. Thorax 2000;55:198-204

82. de Gonzalez AB, Samet JM. What are the cancer risks from using chest computed tomography to manage cystic fibrosis? Am J Respir Crit Care Med 2006;173:139_ 40.

83. Brenner DJ. Estimating cancer risks from pediatric CT: going from the qualitative to the quantitative. Pediatr Radiol 2002;32:228-31

84. Loukides S, Horvath I, Wodehouse $T$, et al. Elevated levels of expired breath hydrogen peroxide in bronchiectasis. Am J Respir Crit Care Med 1998;158:991-4.

85. Horvath I, Loukides S, Wodehouse T, et al. Increased levels of exhaled carbon monoxide in bronchiectasis: a new marker of oxidative stress. Thorax 1998;53:86770.

86. Kharitonov SA, Wells AU, O'Connor BJ, et al. Elevated levels of exhaled nitric oxide in bronchiectasis. Am J Respir Crit Care Med 1995:151:1889-93. 
87. Wark PA, Saltos N, Simpson J, et al. Induced sputum eosinophils and neutrophils and bronchiectasis severity in allergic bronchopulmonary aspergillosis. Eur Respir J 2000;16:1095-101

88. Anderson SD, Brannan JD. Methods for "indirect" challenge tests including exercise, eucapnic voluntary hyperpnea, and hypertonic aerosols. Clin Rev Allergy Immunol 2003;24:27-54.

89. Akalln F, Koroglu TF, Bakac $S$, et al. Effects of childhood bronchiectasis on cardiac functions. Pediatr Int 2003;45:169-74.

90. Edwards EA, Narang I, Li A, et al. HRCT lung abnormalities are not a surrogate for exercise limitation in bronchiectasis. Eur Respir J 2004:24:538-44.

91. Swaminathan S, Kuppurao KV, Somu N, et al. Reduced exercise capacity in noncystic fibrosis bronchiectasis. Indian J Pediatr 2003;70:553-6.

92. Sheehan RE, Wells AU, Copley SJ, et al. A comparison of serial computed tomography and functional change in bronchiectasis. Eur Respir J 2002;20:581-7.

93. Yang IA, Kim ST, Bell SC. Antibiotics in COPD, bronchiectasis and cystic fibrosis. In: Gibson PG, ed. Evidence based respiratory medicine. Malden, Massachusetts: Blackwells, 2005:389-415.

94. Drobnic ME, Sune P, Montoro JB, et al. Inhaled tobramycin in non-cystic fibrosis patients with bronchiectasis and chronic bronchial infection with Pseudomonas aeruginosa. Ann Pharmacother 2005;39:39-44.

95. Scheinberg $\mathbf{P}$, Shore E. A pilot study of the safety and efficacy of tobramycin solution for inhalation in patients with severe bronchiectasis. Chest 2005;127:14206.

96. Orriols R, Roig J, Ferrer J, et al. Inhaled antibiotic therapy in non-cystic fibrosis patients with bronchiectasis and chronic bronchial infection by Pseudomonas aeruginosa. Respir Med 1999:93:476-80.

97. Koh YY, Lee MH, Sun YH, et al. Effect of roxithromycin on airway responsiveness in children with bronchiectasis: a double-blind, placebo-controlled study. Eur Respir J 1997:10:994-9.

98. Evans DJ, Bara Al, Greenstone M. Prolonged antibiotics for purulent bronchiectasis. Cochrane Database Syst Rev 2003:(4).

99. Evans DJ, Greenstone M. Long-term antibiotics in the management of non-CF bronchiectasis - do they improve outcome? Respir Med 2003;97:851-8.

100. Llewellyn-Jones CG, Johnson MM, Mitchell JL, et al. In vivo study of indomethacin in bronchiectasis: effect on neutrophil function and lung secretion. Eur Respir J 1995;8:1479-87

101. Crockett AJ, Cranston JM, Latimer KM et al. Mucolytics for bronchiectasis. Cochrane Database Syst Rev 2001:(1)

102. ten Hacken N, Kerstjens H, Postma D. Bronchiectasis. Clinical Evidence 2005 (accessed 15 Feb 2006).

103. Jones AP, Rowe BH. Bronchopulmonary hygiene physical therapy for chronic obstructive pulmonary disease and bronchiectasis. Cochrane Database Syst Rev 1998:(4)

104. Wills P, Greenstone M. Inhaled hyperosmolar agents for bronchiectasis. Cochrane Database Syst Rev 2002:(1).

105. Kellett F, Redfern J, Niven RM. Evaluation of nebulised hypertonic saline (7\%) as an adjunct to physiotherapy in patients with stable bronchiectasis. Respir Med 2005:99:27-31.

106. Lasserson TJ, Holt K, Milan SJ, et al. Oral steroids for bronchiectasis (stable and acute exacerbations). Cochrane Database Syst Rev 2001:(2)

107. Lasserson T, Holt K, Evans D, et al. Anticholinergic therapy for bronchiectasis. Cochrane Database Syst Rev 2001:(2).
108. Franco F, Sheikh A, Greenstone M. Short acting beta-2 agonists for bronchiectasis Cochrane Database Syst Rev 2003:(1).

109. Sheikh A, Nolan D, Greenstone M. Long-acting beta-2-agonists for bronchiectasis Cochrane Database Syst Rev 2001:(4).

110. Corless JA, Warburton CJ. Leukotriene receptor antagonists for non-cystic fibrosis bronchiectasis. Cochrane Database Syst Rev 2000:(2).

111. Bradley J, Moran F, Greenstone M. Physical training for bronchiectasis. In: Cochrane Library. Cochrane Database Syst Rev 2002:(2)

112. Newall C, Stockley RA, Hill SL. Exercise training and inspiratory muscle training in patients with bronchiectasis. Thorax 2005:60:943-8.

113. Wedzicha JA, Muir JF. Noninvasive ventilation in chronic obstructive pulmonary disease, bronchiectasis and cystic fibrosis. Eur Respir J 2002;20:777-84.

114. Cranston JM, Crockett AJ, Moss JR, et al. Domiciliary oxygen for chronic obstructive pulmonary disease. Cochrane Database Syst Rev 2005:(4).

115. Corless JA, Warburton CJ. Surgery versus non-surgical treatment for bronchiectasis. Cochrane Database Syst Rev 2000:(4).

116. McCool FD. Global physiology and pathophysiology of cough: ACCP evidencebased clinical practice guidelines. Chest 2006:129:48-53S.

117. Otgun I, Karnak I, Tanyel FC, et al. Surgical treatment of bronchiectasis in children J Pediatr Surg 2004;39:1532-6.

118. Dupont $\mathbf{M}$, Gacouin $\mathrm{A}$, Lena $\mathrm{H}$, et al. Survival of patients with bronchiectasis after the first ICU stay for respiratory failure. Chest 2004;125:1815-20.

119. Conaty S, Watson L, Dinnes J, et al. The effectiveness of pneumococcal polysaccharide vaccines in adults: a systematic review of observational studies and comparison with results from randomised controlled trials. Vaccine 2004;22:321424.

120. Benhamou D, Muir JF, Raspaud C, et al. Long-term efficiency of home nasal mask ventilation in patients with diffuse bronchiectasis and severe chronic respiratory failure: a case-control study. Chest 1997:112:1259-66.

121. Gacouin A, Desrues B, Lena $\mathrm{H}$, et al. Long-term nasal intermittent positive pressure ventilation (NIPPV) in sixteen consecutive patients with bronchiectasis: a retrospective study. Eur Respir J 1996:9:1246-50.

122. French J, Bilton D, Campbell F. Nurse specialist care for bronchiectasis. Cochrane Database Syst Rev 2003:(1).

123. Parameswaran K, Pizzichini MM, Li D, et al. Serial sputum cell counts in the management of chronic airflow limitation. Eur Respir J 1998;11:1405-8.

124. Jones AP, Wallis CE, Kearney CE. Recombinant human deoxyribonuclease for cystic fibrosis. Cochrane Database Syst Rev 2003:(3).

125. O'Donnell AE, Barker AF, Ilowite JS, et al. Treatment of idiopathic bronchiectasis with aerosolized recombinant human DNase I. rhDNase Study Group. Chest 1998;113:1329-34.

126. British Thoracic Society. Non-invasive ventilation in acute respiratory failure. Thorax 2002:57:192-211.

127. Daviskas $\mathbf{E}$, Anderson SD, Eberl S, et al. Inhalation of dry powder mannitol improves clearance of mucus in patients with bronchiectasis. Am J Respir Crit Care Med 1999;159:1843-8.

128. Steele K, Greenstone M, Lasserson JA, et al. Oral methylxanthines for bronchiectasis. Cochrane Database Syst Rev 2001:(1).

129. Aaron SD, Vandemheen KL, Ferris W, et al. Combination antibiotic susceptibility testing to treat exacerbations of cystic fibrosis associated with multiresistant bacteria: a randomised, double-blind, controlled clinical trial. Lancet 2005;366:46371. 